CI.Є. Цизь, к.т.н., С.М. Хомич, к.т.н., О.В. Голій, к.т.н. Луцький національний технічний університет

\title{
РЕЗУЛЬТАТИ ДОСЛІДЖЕННЯ ВПЛИВУ ГУМАТІВ САПРОПЕЛЮ НА РІСТ РЕДЬКИ ОЛІЙНОЇ
}

У статті наведена методика та результати дослідження впливу гуматів сапропелю на ріст редьки олійної із використанням математичного методу планування експерименту. Отримано математичну модель досліджуваного процесу у вигляді рівняння peгpeciï. \section{ЗМІШУВАЧ, РЕДЬКА ОЛІЙНА, ГУМАТИ, САПРОПЕЛЬ,} РІВНЯННЯ РЕГРЕСІЇ, ФАКТОР

Постановка проблеми. 3 кожним роком українські аграрії нарощують валовий збір сільськогосподарської продукції. Такі результати досягаються за рахунок інтенсивного використання підвищених норм мінеральних добив. У той же час практично не здійснюються заходи із збереження гумінового комплексу грунтів.

В умовах Волинської області одним із шляхів вирішення проблеми $є$ застосування гумінових органо-мінеральних добрив (ГОМД) на основі озерних сапропелів. Використання місцевого природного сировинного ресурсу забезпечує зниження затрат на приготування ГОМД та загальних витрат.

На теперішній час найбільшого поширення набув метод виготовлення ГОМД, в основі якого лежить властивість гумінових кислот (ГК) взаємодіяти із слабкими розчинами лугів, мінеральних кислот та їх солей з утворенням солей гумінових кислот - так званих, гуматів [1]. 
Специфічна будова сапропелю утруднює виділення з нього ГК. Сапропель характеризується колоїдною будовою, має високу вологість до 97,8\%. Фізично зв'язана вода утворює навколо колоїдних частинок водні оболонки, які перебувають під впливом поверхневих сил натягу. Тому під час механічного перемішування або подрібнення потрібно прагнути до максимальної взаємодії реагенту 3 органічною речовиною сапропелю i виділення максимальної кількості ГК.

Аналіз останніх досліджень і публікацій. Значно підвищити ступінь виділення ГК із сапропелю дозволяє змішувач неперервної, який забезпечує інтенсивний контакт реагентів у тонких плівках [2].

Проте для оцінки якості отриманих ГОМД необхідним $є$ проведення досліджень із їх впливу на ріст та розвиток сільськогосподарських культур. 3 цією метою було розроблено методику вегетаційного дослідження впливу ГОМД виготовлених на основі сапропелю на ріст редьки олійної [3].

Але для всебічного аналізу впливу досліджуваних факторів доцільно мати математичну модель процесу, наприклад у вигляді рівняння регресії. Таке рівняння можна отримати у випадку застосування математичного методу планування експерименту.

Метою даного дослідження $\epsilon$ отримання математичної моделі впливу гуматів сапропелю виготовлених за схемою патенту [2] на ріст редьки олійної у процесі вегетаційного досліду.

Результати дослідження. За результатами попередніх досліджень було встановлено, що на ріст сільськогосподарських культур мають визначальний вплив норма внесення гуматів, концентрація лугу який використовується для приготування гуматів та співвідношення у суміші між лугом та сапропелем. Для кількісної оцінки впливу зазначених факторів та отримання математичної моделі цього процесу у вигляді рівняння регресії, було проведено дослідження із застосуванням математичного методу планування експерименту.

Під час проведення даних досліджень закладались вегетаційні експерменти за методикою описаною у [3].

Для отримання рівняння регресії у вигляді повного квадратного рівняння $\epsilon$ необхідним проведення $\mathrm{N}$ дослідів $[4,5,6]$ :

$$
N=m^{k},
$$

де $m$ - кількість рівнів дослідження; $k$ - кількість факторів у серії досліджень.

Проведення повного факторного експерименту по трьох факторах на трьох рівнях та у трикратній повторності вимагає 
проведення 81-го досліду. Враховуючи трудомісткість дослідів та вплив фактору часу проведення досліджень, було вирішено зменшити кількість дослідів шляхом використання симетричного некомпозиційного плану реалізації експерименту Бокса-Бенкіна другого порядку (табл. 1).

Таблиця 1 - Матриця планування трифакторного експерименту

\begin{tabular}{|c|c|c|c|c|c|c|c|c|c|c|}
\hline 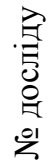 & 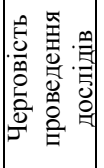 & $\mathrm{x}_{1}$ & $\mathrm{x}_{2}$ & $\mathrm{x}_{3}$ & $\mathrm{x}_{1} \mathrm{x}_{2}$ & $\mathrm{x}_{1} \mathrm{x}_{3}$ & $\mathrm{x}_{2} \mathrm{x}_{3}$ & $\mathrm{x}_{1}^{2}$ & $\mathrm{x}_{2}^{2}$ & $x_{3}{ }^{2}$ \\
\hline 1 & 6 & +1 & +1 & 0 & +1 & 0 & 0 & +1 & +1 & 0 \\
\hline 2 & 1 & -1 & +1 & 0 & -1 & 0 & 0 & +1 & +1 & 0 \\
\hline 3 & 12 & +1 & -1 & 0 & -1 & 0 & 0 & +1 & +1 & 0 \\
\hline 4 & 3 & -1 & -1 & 0 & +1 & 0 & 0 & +1 & +1 & 0 \\
\hline 5 & 4 & +1 & 0 & +1 & 0 & +1 & 0 & +1 & 0 & +1 \\
\hline 6 & 7 & -1 & 0 & +1 & 0 & $\begin{array}{l}-1 \\
\end{array}$ & 0 & +1 & 0 & +1 \\
\hline 7 & 2 & +1 & 0 & -1 & 0 & -1 & 0 & +1 & 0 & +1 \\
\hline 8 & 10 & -1 & 0 & -1 & 0 & +1 & 0 & +1 & 0 & +1 \\
\hline 9 & 15 & 0 & +1 & +1 & 0 & 0 & +1 & 0 & +1 & +1 \\
\hline 10 & 8 & 0 & -1 & +1 & 0 & 0 & -1 & 0 & +1 & +1 \\
\hline 11 & 4 & 0 & +1 & -1 & 0 & 0 & -1 & 0 & +1 & +1 \\
\hline 12 & 13 & 0 & -1 & -1 & 0 & 0 & +1 & 0 & +1 & +1 \\
\hline 13 & 9 & 0 & 0 & 0 & 0 & 0 & 0 & 0 & 0 & 0 \\
\hline 14 & 5 & 0 & 0 & 0 & 0 & 0 & 0 & 0 & 0 & 0 \\
\hline 15 & 14 & 0 & 0 & 0 & 0 & 0 & 0 & 0 & 0 & 0 \\
\hline
\end{tabular}

Планування і проведення експериментальної роботи включало наступні етапи:

- кодування факторів;

- складання плану-матриці експерименту;

- рандомізація дослідів;

- реалізація плану експерименту;

- перевірка відтворюваності дослідів;

- оцінка значущості коефіцієнтів регресії;

- перевірка адекватності моделі.

Під час складання таблиці факторів і рівнів варіювання (табл. 2) враховували результати попередніх досліджень і 
інформацію, отриману із літературних джерел.

Таблиця 2 - Фактори і рівні варіювання

\begin{tabular}{|c|c|c|c|}
\hline \multirow{3}{*}{$\begin{array}{l}\text { Рівні } \\
\text { варіювання }\end{array}$} & \multicolumn{3}{|c|}{ Фактори } \\
\hline & \begin{tabular}{|c|} 
Концентрація \\
лугу $k, \%$ \\
\end{tabular} & $\begin{array}{c}\text { Норма внесення } Q, \\
\text { т/га } \\
\end{array}$ & $\begin{array}{c}\text { Відносний } \\
\text { вміст лугу, } m\end{array}$ \\
\hline & $\mathrm{x}_{1}$ & $\mathrm{x}_{2}$ & $\mathrm{x}_{3}$ \\
\hline Верхній (+1) & 6 & 15 & 1,2 \\
\hline Основний $(0)$ & 4 & 10 & 1 \\
\hline Нижній (-1) & 2 & 5 & 0,8 \\
\hline $\begin{array}{c}\text { Інтервал } \\
\text { варіювання, } \varepsilon\end{array}$ & 2 & 5 & 0,2 \\
\hline
\end{tabular}

Кодування факторів здійснювали для переведення їх у безрозмірні величини. Зв'язок між закодованими і натуральними величинами факторів встановлювався залежностями:

$$
x_{1}=\frac{k-k_{0}}{\varepsilon_{2}} x_{2}=\frac{Q-Q_{0}}{\varepsilon_{1}} ; x_{3}=\frac{m-m_{0}}{\varepsilon_{3}},
$$

де $Q_{0}, k_{0}, m_{0}$ - значення факторів на основному рівні, відповідно норма внесення гуматів сапропелю, концентрація лугу, що використовувався для приготування гуматів, співвідношення між вмістом лугу та сапропелю під час приготування гуматів; $\varepsilon_{1}, \varepsilon_{2}, \varepsilon_{3}$ - інтервал варіювання фактора.

Для трифакторного досліду повне квадратне рівняння має вид:

$$
\begin{aligned}
& \bar{y}=b_{0}+b_{1} x_{1}+b_{2} x_{2}+b_{3} x_{3}+b_{11} x_{1}^{2}+b_{22} x_{2}^{2}+b_{33} x_{3}^{2}+ \\
& +b_{12} x_{1} x_{2}+b_{13} x_{1} x_{3}+b_{23} x_{2} x_{3} \text {. }
\end{aligned}
$$

Коефіцієнти регресії визначають за наступними формулами [4]:

$$
\begin{gathered}
b_{0}=\frac{1}{n_{0}} \sum_{u=1}^{n_{0}} y_{0_{u}}, \\
b_{j}=\frac{1}{8} \sum_{i=1}^{n} x_{j i} y_{i}, \\
b_{j r}=\frac{1}{4} \sum_{i=1}^{n} x_{j i} x_{r i} y_{i},
\end{gathered}
$$




$$
b_{j j}=\frac{1}{4} \sum_{i=1}^{n} x_{j i}^{2} y_{i}-\frac{1}{16} \sum_{j=1}^{p} \sum_{i=1}^{n} x_{j i}^{2} y_{i}+\frac{1}{2 n_{0}} \sum_{u=1}^{n_{0}} y_{0_{u}},
$$

де $u$ - номер досліду в центрі плану;

$n_{0}$ - кількість дослідів в центрі плану;

$r, j$ - номери фактору досліду, причому у формулі (6) $r \neq j$;

$p$ - кількість факторів;

$i$ - номер досліду;

$n$ - кількість дослідів;

$y_{i}$ - значення функції відгуку в і-му досліді;

$x_{j i}, x_{r i}-$ кодовані значення ј-го чи r-го фактору в і-му досліді;

$y_{0_{u}}-$ значення функції відгуку в u-му досліді в центрі плану.

Оскільки експерименти проводились із однаковим числом повторностей, то однорідність ряду дисперсій перевіряли за критерієм Кохрена [4]. Для цього визначали розрахункову величину даного критерію:

$$
G^{\text {розр. }}=\frac{S_{y_{i} \max }^{2}}{\sum_{i=1}^{n} S_{y_{i}}^{2}},
$$

де $S_{y_{i} \text { max }}^{2}$ - найбільша із дисперсій;

$\sum_{i=1}^{n} S_{y_{i}}^{2}$ - дисперсія, що характеризую розсіювання результатів в іму досліді.

$$
S_{y_{i}}^{2}=\frac{1}{m-1} \sum_{g=1}^{m}\left(y_{i g}-\bar{y}_{i}\right)^{2},
$$

де $m$ - число повторностей в досліді;

$\mathrm{g}$ - номер повторності;

$y_{i g}$ - результат g-ї повторності і-го досліду;

$\bar{y}_{i}-$ середнє арифметичне значення усіх повторностей і-го досліду.

Ряд дисперсій рахували однорідним, якщо:

$$
G^{\text {розр. }}<G^{\text {табл. }}(0.05 ; n ; f),
$$

де $G^{\text {табл. }}(0.05 ; n ; f)$ - табличне значення критерію Кохрена за 5\%го рівня значущості, n-ї кількості дослідів та $f=m-1$ - числа ступенів вільності.

Дисперсію відтворюваності експерименту визначали за 
результатами дослідів в центрі плану за формулою:

$$
S_{y}^{2}=\frac{\sum_{u=1}^{n_{0}}\left(y_{0_{u}}-\bar{y}_{0}\right)^{2}}{f_{l}},
$$

де $\bar{y}_{0}-$ середнє арифметичне значення функції відгуку отримане за результатами $n_{0}$ дослідів в центрі плану;

$f_{l}=n_{0}-1$ - число ступенів вільності дисперсії відтворюваності.

Дисперсію коефіцієнтів регресії та їх коваріації визначали за формулами:

$$
\begin{gathered}
S_{b_{0}}^{2}=\frac{1}{n_{0}} S_{y}^{2} ; \\
S_{b_{j}}^{2}=0.125 S_{y}^{2} ; \\
S_{b_{j r}}^{2}=0.25 S_{y}^{2} ; \\
S_{b_{j j}}^{2}=0.27083 S_{y}^{2} ; \\
\operatorname{cov}_{b_{0} b j j}=-0.16667 S_{y}^{2} ; \\
\operatorname{cov}_{b_{j j} b_{r r}}=0.02083 S_{y}^{2} .
\end{gathered}
$$

Довірчі інтервали коефіцієнтів регресії знаходили використовуючи табличне значення критерію Ст'юдента $t(0.05 ; f)$ за $5 \%$-го рівня значущості та $f=n_{0^{-}}-$- числа ступенів вільності в центрі плану:

$$
\begin{aligned}
& \Delta b_{0}=t(0.05 ; f) S_{b_{0}} ; \\
& \Delta b_{j}=t(0.05 ; f) S_{b_{j}} ; \\
& \Delta b_{j r}=t(0.05 ; f) S_{b_{j r}} ; \\
& \Delta b_{j j}=t(0.05 ; f) S_{b_{j j}} .
\end{aligned}
$$

Якщо коефіцієнт регресії виявлявсь меншим довірчого інтервалу, то його вважали статично не значним. Проте, видаляли iз моделі лише ті коефіцієнти, які не корелювали ні з яким іншим. Оскільки, у протилежному випадку, рівняння регресії може виявитись неадекватним.

Гіпотезу адекватності отриманої моделі перевіряли за допомогою $F$-критерію (критерію Фішера). Його розрахункове значення визначали за формулою: 


$$
F^{\text {розр. }}=\frac{S_{\text {неад. }}^{2}}{S_{y}^{2}} \text {. }
$$

Дисперсія неадекватності $S_{\text {неад. }}^{2}$ становить:

$$
S_{\text {неад. }}^{2}=\frac{\sum_{i=1}^{n}\left(\bar{y}_{i}-y_{i}\right)^{2}}{i_{2}},
$$

де $y_{i}, \bar{y}_{i}$ - значення функції відгуку і-го досліду, визначене відповідно експериментально та за рівнянням регресії;

$i_{2}=n-k^{\prime}$ - число ступенів вільності дисперсії неадекватності 3 врахуванням числа $k^{\prime}$ залишених коефіцієнтів регресії (у тому числі і $\mathrm{b}_{0}$ ).

Гіпотезу про адекватність рівняння приймали у тому випадку, коли розраховане значення $F$-критерію не перевищувало табличне:

$$
F^{\text {розр. }} \leq F^{\text {табл. }}\left(0.05 ; f_{2} f_{1}\right),
$$

де $F^{\text {табл. }}\left(0.05 ; f_{2} f_{1}\right)$ - табличне значення критерію Фішера за 5\%-го рівня значущості і ступенів вільності дисперсії неадекватності $f_{2}$ та дисперсії відтворюваності $f_{l}$.

Метою реалізації експеримету було визначення зміни висоти рослин редьки олійної на 10 день після закладання експерименту за варіювання таких факторів як: норма внесення гуматів сапропелю, концентрація лугу, що використовувався для приготування гуматів, співвідношення між вмістом лугу та сапропелю під час приготування гуматів.

Обробка даних трифакторного експерименту, проведеного за симетричним некомпозиційним планом Бокса-Бенкіна другого порядку, здійснювалась на ПЕОМ розробленою програмою у середовищі Mathcad При цьому однорідність ряду дисперсій перевіряли за критерієм Кохрена (8). Оскільки, $G^{\text {posp. }}=0,333<$ $G^{\text {табл. }}(0.05 ; 15 ; 2)=0.335$ [4] то процес відтворюється.

При визначення довірчих інтервалів коефіцієнтів регресії використовували критерій Ст'юдента, табличне значення якого при 5-\% рівні значущості та числі ступенів вільності дисперсії відтворюваності досліду $f_{l}=2$ становило $t=4.3$ [4].

Перевірку значущості коефіцієнтів регресі проводили за встановленими їх довірчими інтервалами та коваріаціями. У результаті рівняння регресії набуло вигляду: 


$$
\bar{y}=9,256+0,75 x_{1}+0,55 x_{2}+0,517 x_{2}-0,369 x_{1}^{2}-0,403 x_{2}^{2}+0,297 x_{3}^{2} .
$$

Перевірку гіпотези адекватності отриманого рівняння регресії (25) проводили за критерієм Фішера. Розрахункове значення даного критерію при дисперсії неадекватності $S_{\text {неад. }}^{2}=0,244$ і дисперсії відтворюваності досліду $S_{y}^{2}=0,111$ становило: $F^{p o з p . ~}$ $=2,185$. Табличне значення критерію Фішера за прийнятого 5-\% значущості, згідно [4], склало:

$$
F^{\text {табл. }}\left(0.05 ; f_{2} ; f_{1}\right)=19,38,
$$

де $f_{2}=8$ - число ступенів вільності дисперсії неадекватності;

$f_{l}=2$ - число ступенів вільності дисперсії відтворюваності досліду.

Оскільки, $\quad F^{\text {розр. }}=2,185<F^{\text {табл. }}\left(0.05 ; f_{2} ; f_{1}\right)=19,38, \quad$ то гіпотеза адекватності рівняння регресії підтверджується.

Остаточно рівняння регресії із факторами у натуральному вигляді запишеться:

$$
\begin{aligned}
y= & 8,408+1,113 \cdot k+0.4324 \cdot Q-12,265 \cdot m- \\
& -0,09225 \cdot k^{2}-0,01612 \cdot Q^{2}+7,425 \cdot m^{2} .
\end{aligned}
$$

За отриманим рівнянням регресії (26) були побудовані поверхні відгуку (рис. 1, а) та графіки ліній рівня (рис. 1, б) для відслідковування динаміки зміни висоти рослин (впливу гуматів сапропелю на ріст рослин). 


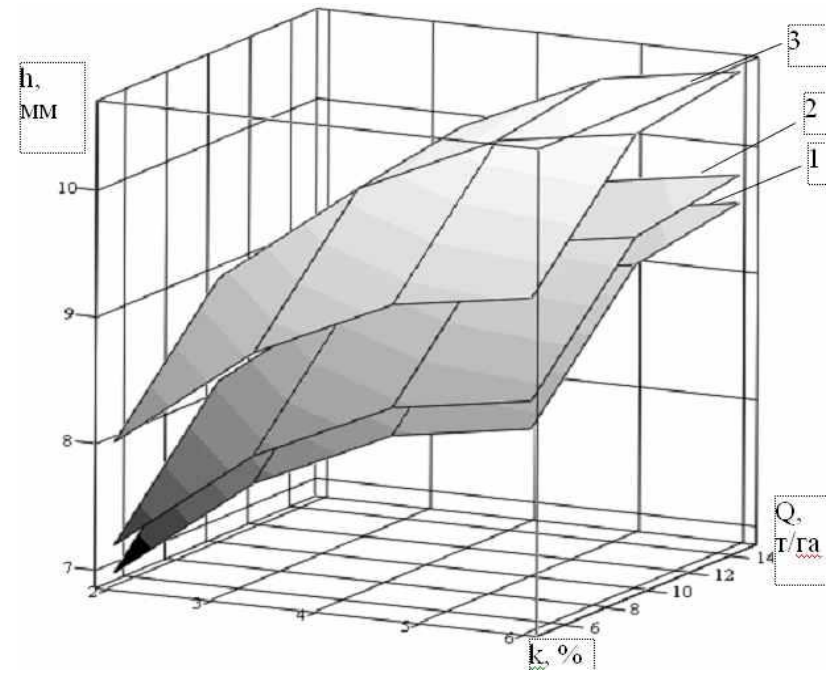

a

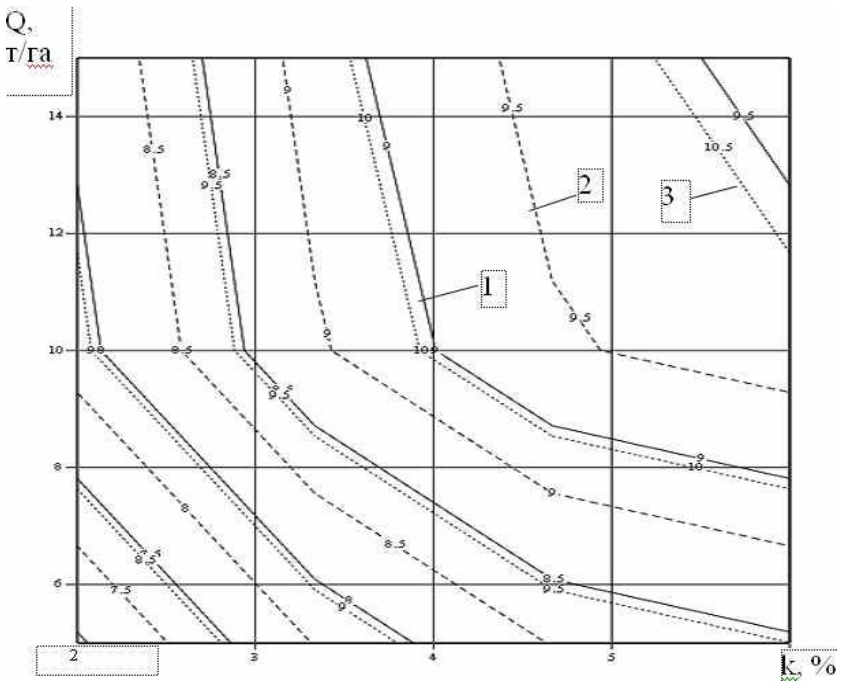

6

Рис. 1 - Залежність зміни висоти рослин редьки олійної від норми внесення гуматів сапропелю $Q$ та концентрації лугу $k$, що використовувався за співвідношення між лугом та сапропелем: 1 $m=0,8 ; 2-m=1,0 ; 2-m=1,2$ 
Висновоки. Розроблене методика визначення впливу гуматів сапропелю на ріст сільськогосподарських культур заснована на використанні плану реалізації експерименту БоксаБенкіна другого порядку, дозволяє отримати математичну модель процесу вигляді рівняння регресії. Функцією відгуку отриманого рівняння є висота рослин на 10 день після посіву.

Аналіз отриманого рівняння регресії показує, що всі досліджувані фактори мають суттєвий вплив на ріст редьки олійної, а не співвідношенням між ними, оскільки, всі ефекти парних взаємодій виявились статистично незначущими. Також можна зробити висновок, що спостерігається активне збільшення приросту рослинної маси редьки олійної при внесенні гуматів сапропелю у межах 10-12 т/га та концентрації лугу, який використовувався для приготування гуматів у межах 3-4 \%. Подальше збільшення даних параметрів збільшує вплив складової другого порядку в рівнянні регресії (26), яка має від'ємне значення.

\section{Література}

1. Безуглова О.С. Новый справочник по удобрениям и стимуляторам роста. - СПб.: Феникс, 2003. - 382 с.

2. Пат. 30412 Ураїни, МПК В01F9/00. Змішувач безперервної дії / Цизь І.Є., Величко В.Л. - № u 200712181; Заявл. 05.11.2007; Опубл. 25.02.2008. Бюл. №8. - 2 с.

3. Цизь I.Є., Хомич С.М., Величко В.Л., Патер Х.С., Радчук І.П. / Сільськогосподарські машини: Зб.наук.ст. - Вип. 39. Луцьк, 2018. - С. 151-158.

4. Новик Ф.С., Арсов Я.Б. Оптимизация процессов технологии металлов методами планирования єэкспериментов. М.: Машиностроение; София: Техника, 1980. 304 с.

5. Хайліс Г.А., Коновалюк Д.М. Основи проектування i дослідження сільськогосподарських машин: Навчальний посібник. - К.: НМК ВО, 1992. -320 с.

6. Мельников С.В. и др. Планирование эксперимента в исследованиях сельскохозяйственных процессов / С.В. Мельников, В.Р. Алёшкин, П.М. Рощин. - 2-е изд., перераб. И доп. -Л.: Колос. Ленингр. Отд-ние, 1980. - 168 с. 